\title{
THE ECONOMICS OF COUNTERINSURGENCY: SOME EVIDENCE FROM ANDHRA
}

\section{PRADESH}

\section{SAURABH SINGHAL}

Saurabh Singhal is a Research Fellow at the World Institute for Development Economics Research. He may be reached at saurabh@wider.unu.edu. Smriti Sharma and anonymous referees are thanked for comments. The findings, interpretations, and views expressed in this article are solely those of the author.

\section{Abstract}

Present in India since the 1960s, the Naxalite insurgency has steadily spread across the country. Counterinsurgency measures lagged behind and did not follow any systematic process till the early 2000s with the exception of Andhra Pradesh, which in 1989 established the Greyhounds, an anti-Naxalite police force. However, under the Congress-led UPA government (in power since 2004), there has been a concerted effort to tackle the insurgency. This article analyzes the centrally funded Security Related Expenditure Scheme in the context of industrial investments in Andhra Pradesh over the period 2005-2009. I find the scheme to have had no effect on industrial credit at the district level. A further disaggregation of the industrial credit data reveals no effects on construction but finds a positive effect on mining and quarrying activity.

$\mathrm{S}$ ince its independence, India has been besieged with insurgencies but none have been as enduring as the Naxalite insurgency that currently affects approximately a third of the country's districts, mostly along its eastern seaboard. In India, internal security is primarily the responsibility of the states but in 2005, India's central government expanded a centrally funded Security Related Expenditure (SRE) scheme to compensate states for counterinsurgency expenditures. Despite the government's substantial reliance on this policy, no systematic study has evaluated the efficacy of this policy. This study provides a preliminary evaluation measured in terms of industrial investments made in Andhra Pradesh, a southeastern state, during the new phase of the SRE scheme. The analysis reveals no effects on the construction sector but finds a positive effect on mining and quarrying activity.

Long a hub of Naxalite violence, Andhra Pradesh state was one of the first movers on the counterinsurgency front and in 1989 established a highly trained and motivated anti-Naxalite police force, called the Greyhounds. The progress of counterinsurgency policies is difficult to judge. The notion of front lines does not exist in the traditional sense and the literature has typically relied on measures such as kill-ratios. Recently, however, researchers and practitioners have argued for using economic indicators to assess the progress of counterinsurgency. In addition to the loss of life and property, conflicts cause political instability, which adversely affects saving and investment and results in the loss of economic prosperity. Reduced economic growth can then make a region vulnerable to further political and financial instability.

Counterinsurgency policies, by reducing uncertainties and boosting confidence, may enhance investment and demand. Literature along these lines includes the use of exchange rates to determine the effectiveness of U.N. interventions in Lebanon, the use of equity price indices to assess the prospects of sustainable peace in Sri Lanka, and economic indicators such as bond prices, and of oil and electricity production, to assess recent policies in Iraq. ${ }^{1}$ As for India, a 2012 paper analyzed the economic effects of the introduction of the Greyhounds in Andhra Pradesh. The present article analyzes the effectiveness of the centrally funded SRE scheme in Andhra Pradesh, particularly in regard to the amount of industrial investment undertaken in the state. ${ }^{2}$

\section{Insurgency and counterinsurgency}

Initially led by radical members of the Communist Part of India (Marxist), the Naxalite movement started as an armed peasant uprising in Naxalbari village in West Bengal in 1967 and then rapidly spread to other parts of India. It aims to overthrow the Indian state and establish a communist regime. Due to both a heavy response from the state and political infighting, the movement splintered into various subgroups and was largely driven underground by the early 1970s.

In Andhra Pradesh, the movement reappeared strongly with the formation of the Communist Party of India (Marxist-Leninist) People's War (also called People's War Group) under the leadership of Kondapalli Seetharamaiah in 1980. While there was little intergroup coordination in the 
movement's early phases, quite a few mergers occurred from the mid-1990s onwards. The most significant merger took place in 2004 when the two largest Naxalite groups - the People's War Group in Andhra Pradesh and the Maoist Communist Centre of India (MCCI) in Bihar - merged to form the Communist Party of India (Maoist), or CPI (Maoist). By the government's estimate, 223 districts across 20 states were affected in 2008. In 2006, the Prime Minister of India described the Naxalite problem as the single biggest internal security challenge that the country then faced. ${ }^{3}$

In addition to the rapid spread to the insurgency, another cause of concern was (and is) the increasing lethality of weapons used by Naxalites, moving from homemade weapons to sophisticated rifles (such as the Kalashnikov series and INSAS rifles), light machine guns, rocket launchers, and mines. For example, in 2003, Mr. N. Chandababu Naidu, Chief Minister of Andhra Pradesh, barely escaped a land mine attack by the People's War Group. ${ }^{4}$

Naxalites disrupt the local economy in their areas of operation by destroying public infrastructure such as railway lines, communication towers, roadways, public offices, and schools. One estimate puts the cost of a two-day long economic blockade by Naxalites in June 2007 that targeted public infrastructure at Rs. 1.5 billion. Economic activity is also affected by the increasing incidence of kidnapping for ransom and protection money levied on commercial enterprises. For example, one report on documents seized from Naxalites by the police in 2007 suggests CPI (Maoist) revenue of well over Rs. 10 billion, a large part of which came from extortions. The insecurity created by Naxalite activity has been reported to dampen investments in the affected areas. ${ }^{5}$

Counterinsurgency policies in response to Naxalite activity differs from those of other insurgencies in India in two key ways. First, there is no (direct) involvement of the Indian army and, second, because the insurgency is spread over a large geographical area, state coordination is required. In India, maintenance of law and order is the responsibility of the states and until recently, there was little coordination between the central and the state governments on the approach toward the insurgency. Left to their own devices, the response from the affected states was lacking, with the states largely relying on inadequately trained regular police forces. The central government does step in with support from the central police organizations when requested, but this has been widely acknowledged to have had little effect. From 2005 onward, under the Congress-led UPA government, however, a concerted effort has been made to increase coordination between the affected states and the central government. ${ }^{6}$
Since independence, India has been affected by various violent insurgencies, particularly in states along its eastern seaboard. One such state is the southeastern state of Andhra Pradesh, The article analyzes the effectiveness of India's centrally funded Security Related Expenditure (SRE) scheme, which reimburses states for expenditures incurred in fighting the Naxalite insurgency. Particular attention is paid to the amount of industrial investment undertaken in Andhra Pradesh during the new phase of the SRE scheme.

The Security Related Expenditure (SRE) scheme for Naxalite-affected areas

With many affected states falling short of funds to maintain and improve the state police, the central government implemented the SRE scheme to help fund anti-Naxalite operations in affected districts. The scheme initially operated on a small scale (and often in an ad hoc manner) from 1996 to 2004 , covering a few districts and only providing 50 percent reimbursement of police expenditure incurred on anti-Naxalite operations.

In 2005, under the new UPA government, the scheme was comprehensively revised. The extent of coverage increased considerably both in terms of the number of districts and the types of expenditure covered. Also, the amount of reimbursement spiked from 50 percent to 100 percent. Among other things, the scheme provides reimbursement for weapons, transportation and communication equipment, special training of state police personnel, provision of insurance for state police personnel, ex gratia payment to families of civilians or security personnel killed, rehabilitation of surrendered Naxalites, and community policing. ${ }^{?}$

Under the revised scheme, selection is a two-step process. First, a state is eligible if there exist banned Naxalite groups in the state, if the state has made efforts to tackle the activities of these groups, and if Naxalite activity has hindered development. Second, the eligibility of a district is based on the intensity of Naxalite violence over the past three to five years, the organization of the Naxal groups (even if violence is low), the sophistication of arms used by Naxalites, the presence of front organizations that lend local support, and the measures taken by the local administration.

In terms of geographical coverage, the scheme has expanded from an initial list of 27 districts in 5 states in 1996 to 83 districts across 9 states in $2005 .{ }^{8}$ Figure 1 shows the approximate geographical coverage under the scheme. Figure 2 shows the total amount of funds released by the central government to the affected states. The average of annual funds released during the period 2000-2004 was Rs. 150 million. This increased under the new scheme. Over the period 
2005-2009, the annual funds released averaged well over half a billion rupees (Rs. 592 million). ${ }^{9}$ Similarly, the funds released to Andhra Pradesh doubled from an average of Rs. 37.2 million per annum during 2000-2004 to Rs. 76.3 million per annum during 2005-2009.

The scheme appears to have (partly) met a genuine need for additional funds in the affected states. Faced with repeated requests to increase the number of districts covered by the scheme, the central government expanded the list to 106 districts in 2012 and increased its financial commitment further. ${ }^{10}$

\section{Andhra Pradesh's Greyhounds}

In 1989, Andhra Pradesh raised a special state police force, known as the Greyhounds, to counter the Naxalites. This commando force is well-trained in counterinsurgency methods, highly remunerated, well-equipped, and has its own intelligence network. Its members are recruited from the regular police forces for a tenure of three years after which they return to their respective units. The Greyhounds have been widely credited by security experts and policymakers with bringing Naxalite violence in Andhra Pradesh under control. ${ }^{11}$

The Greyhounds force is reported to be the idea of Mr. V.S. Vyas, an officer of the Indian Police Service. Although, Mr. Vyas was assassinated by Naxalites in 1993, the force survived and has grown in numbers from 886 in 1989 to around 2,000 in 2009. Since 2000, the Greyhounds have been providing training to the police forces of other Naxalite-affected states and at the request of the Prime Minister, Dr. Manmohan Singh, some of these states are reportedly raising similar forces themselves. $^{12}$

A 2012 paper examines the extent to which the creation of the Greyhounds mitigated economic losses due to Naxalite violence in Andhra Pradesh. It finds that per capita GDP in Andhra Pradesh over the period 1989-2000 was 16 percent higher than it would have been in the absence of the Greyhounds. This positive effect is traced to the nonagricultural sectors of the state economy and, in particular, to the manufacturing sector and its components (registered and unregistered manufacturing), with effects ranging from 20 to 26 percent increase in the average sectoral output. ${ }^{13}$

These outcomes capture direct and indirect effects of the introduction of the Greyhounds. After all, they do not operate in isolation. Reportedly, good coordination and intelligence sharing takes place with the regular Andhra Pradesh police force, and Greyhound members return to their respective units after their tenure, and this has over time contributed to improved counterinsurgency capabilities of the regular police force as well. ${ }^{14}$

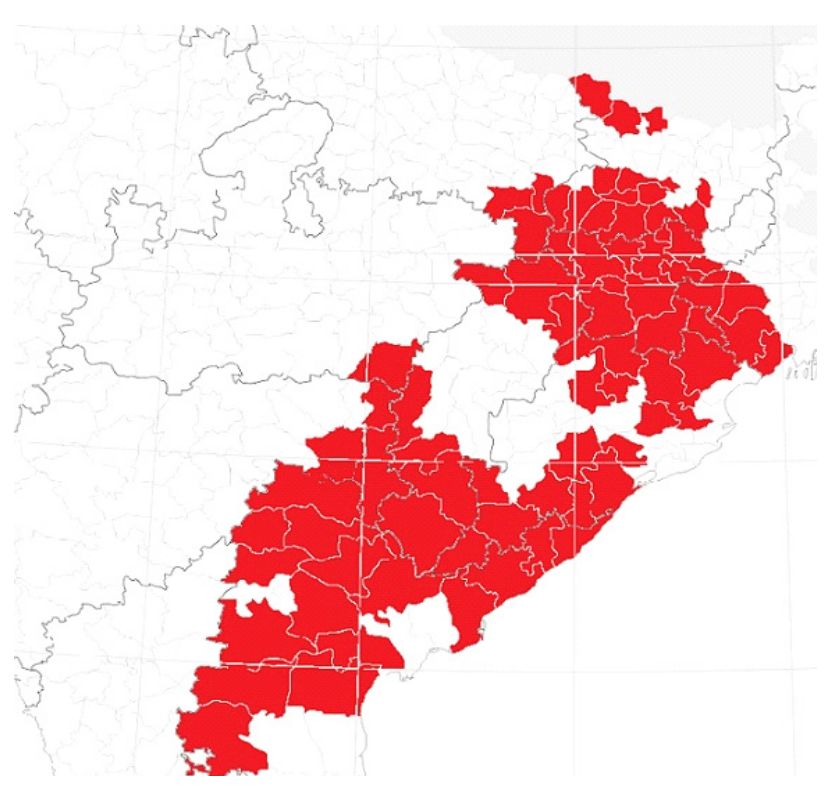

Figure 1: Districts under the SRE scheme. Note: District boundaries have changed over time. The figure is an approximate representation of the districts covered under SRE during 2005-2009.

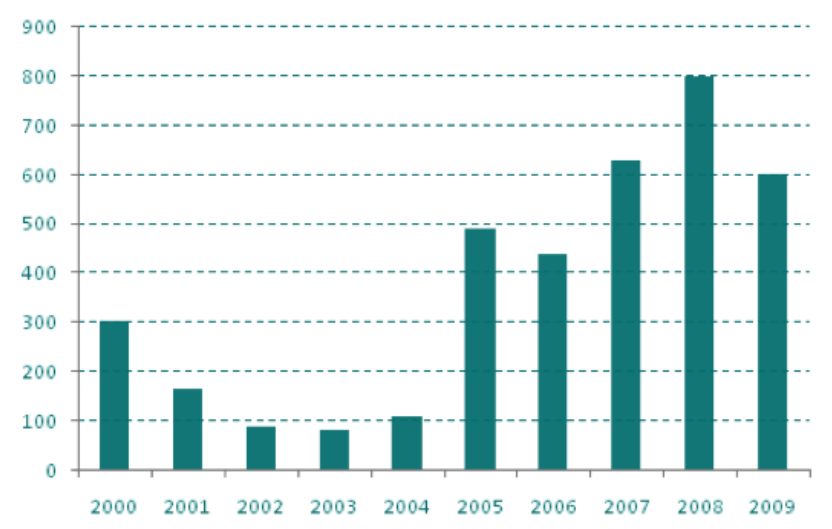

Figure 2: Funds released under the SRE scheme for Naxalite-affected States (in Rs. millions; 2000-2001 to 2009-2010). Note: Author's calculations based on data from the Ministry of Home Affairs.

\section{Data and empirical strategy}

The empirical research reported here uses the synthetic control method (SCM) developed by Abadie and Gardeazabal for the Basque economy in Spain to estimate how an economy would have grown in the absence of the counterinsurgency policy response. In simple terms, the SCM uses pre-intervention (or pre-"treatment") information on the outcome variables and predictors of interest to weight the control variables in such a way as to resemble the treated unit, thereby creating a "synthetic control." The counterfactual outcome for the treated 
unit in post-intervention periods can then be estimated from the outcome for the synthetic control. An extension of the difference-in-difference methodology, SCM relaxes the assumption of a common linear trend between the treated and the control areas in the absence of treatment. ${ }^{15}$

The SCM can be motivated through the following framework. ${ }^{16}$ Suppose we have panel data on $J+1$ regions for $T$ periods of time. Only the first region exposed to the treatment from periods $T_{o}+1$ to $T$ and the remaining $J$ regions are the controls. The treatment on region $i$ at time $t$ can be written as $\alpha_{\mathrm{it}}=\mathrm{Y}_{\mathrm{it}}{ }^{\mathrm{I}}-\mathrm{Y}_{\mathrm{it}}{ }^{\mathrm{N}}$, where the two terms on the right-hand side of the equation denote the outcome with and without treatment, respectively. To estimate the treatment effect for region $1\left(\alpha_{1, \mathrm{To}+1, \ldots, \alpha 1, \mathrm{~T}}\right)$, one needs to estimate what the outcome would have been in the absence of treatment for region 1 . Assume that $\mathrm{Y}_{\mathrm{it}}{ }^{\mathrm{N}}$ is given by the following model:

(1) $Y_{i t}^{N}=\delta_{t}+\theta_{t} Z_{i}+\lambda_{t} \mu_{i}+\epsilon_{i t}$

Here, $Z_{i}$ is a vector of observed covariates (which may vary with time, but are not affected by the treatment), $\mu_{i}$ are the region-specific unobserved confounders, and $\epsilon_{i t}$ are mean 0 shocks. Let

(2) $W=\left\{\omega_{j}\right\}_{j=2}^{J+1}$

be a set of non-negative weights that sum to one. Each such set of weights represents a particular weighted average of controls, i.e., a particular synthetic control. It can be shown ${ }^{17}$ that if there exists a set of weights $\mathrm{W}^{*}$ such that

(3) $Z_{1}=\sum_{j=2}^{J+1} \omega_{j}^{*} Z_{j}$ and $Y_{1 t}=\sum_{j=2}^{J+1} \omega_{j}^{*} Y_{j t}$ for all $t \in\left\{1, \ldots, T_{0}\right\}$

then the treatment effect can be estimated from

(4) $\hat{\alpha}_{1 t}=Y_{1 t}-\sum_{j=2}^{J+1} \omega_{j}^{*} Y_{j t}^{N}$.

In words, the counterfactual outcome for the treated unit in post-treatment periods can be estimated from the weighted average of the outcomes of the controls. In practice, the weights $W^{*}$ are chosen such that equation (3) holds approximately. Let $X_{1}$ be the vector of pre-treatment characteristics of the treated region and $X_{0}$ be the matrix of pre-treatment characteristics of the control region. Then the vector of weights $W^{*}$ is chosen to minimize the square root of $\left(X_{I}-X_{0} W\right)^{\prime} V\left(X_{I}-X_{0} W\right)$ subject to the weights being non-negative and summing to 1 . Although $V$ can be any positive definite matrix, $V$ is chosen such that the mean square error of the outcome variable is minimized for the pre-treatment period.

The SCM does not allow for inference through the standard asymptotic techniques. Following the literature, we check the significance of the results through placebo tests where the same analysis is performed on each of the potential controls (as if they were treated) and then compared to the baseline results. ${ }^{18}$ If the actual treatment effects (baseline) are large relative to the placebos then the result is significant.

This article reports estimates of the economic effects of the SRE scheme in Andhra Pradesh above and beyond any effects of the Greyhounds, and specifically effects on its industrial sector which during the period under consideration accounts, on average, for 25 percent of state GDP. Further, within the industrial sector, the effects on the mining and quarrying and the construction sector are of special interest. Although accounting for less than 3 percent of state GDP, mining and quarrying are of strategic importance. For example, in 2009-2010, Andhra Pradesh accounted for 10.7 percent of the value of mineral output in the whole of continental India, making it the country's most important state in this regard. The state is also a key producer of certain principal minerals such as barytes and mica, accounting for over 99 percent of India's total output. And considering the recent evidence from Northern Ireland that housing prices respond to a decline in violence, the article also reports on the effect of the SRE scheme on construction activity in Andhra Pradesh. ${ }^{19}$

District-level investment measures used are (1) the total amount of industrial credit disbursed by so-called scheduled commercial banks and (2) industrial credit disbursed under the subcategories of mining and quarrying and construction. Scheduled commercial banks include public, private (domestic and foreign), and cooperative banks registered with the Reserve Bank of India. They are the primary source of official credit. Although not including investments financed through other channels such as capital and unofficial money markets, scheduled commercial banks' credit is probably the best available indicator of investment. The data is compiled yearly and available through the Basic Statistical Returns of the Scheduled Commercial Banks of India reports published by the Reserve Bank of India.

The observed covariates used in the construction of the synthetic control are (1) the percentage of the district population that belongs to the Scheduled Caste and Scheduled Tribes (SC and ST, respectively), (2) population density, (3) the percentage of the population living in urban areas, (4) the literacy rate, (5) average household consumption expenditure, (6) the Gini coefficient, (7) the unemployment rate, and (8) 
district-level Naxalite activity, coded into an index that ranges from 0 for not affected to 4 for highly affected. ${ }^{20}$

Andhra Pradesh has 23 districts, 16 of which were covered ("treated") under the SRE scheme. The simple average of these districts forms the treated unit while the potential controls (untreated) are the remaining 7 districts in the state. Since the SRE scheme was introduced in 2005 , the pre-treatment period is $1999-2004$ and the post-treatment period is $2005-2009 .^{21}$

The analysis is terminated in 2009 as the central government launched two other important counterinsurgency policies thereafter. First, in November 2009 the government launched a massive coordinated paramillitary offensive across five states against the Naxalites ("Operation Green Hunt"). Second, in November 2010, the central government launched the Integrated Action Scheme to improve the provision of public goods and services in Naxalite-affected districts. ${ }^{22}$

\section{Results}

Pre-treatment covariates and outcomes are used to weight the controls in such a way that they resemble the treated unit in the pre-treatment period. The resulting synthetic control consists of three districts: Cuddapah (42 percent), Nellore (37 percent), and Rangareddy (21 percent). Weights and predictor means used to construct the synthetic control are shown in Tables 1 and 2. The synthetic control constructed using the weights mirrors the treated unit fairly well on all predictors. In particular, the synthetic control does a much better job in resembling the treated unit than, for example, the equally weighted average of the controls.

A visual representation of the SCM indicates little evidence of a treatment effect of the SRE scheme on total industrial credit taken in Andhra Pradesh (see Figure 3). Industrial credit taken in the treated unit (that is, the districts receiving SRE funds) is represented by the solid black line. The synthetic control-the untreated districts-is shown by the dashed line and closely mirrors the treated trend in industrial credit taken until 2004, after which there is a slight divergence. Even though there is a steady increase in industrial credit taken in the treated unit, the synthetic control catches up and exceeds the treated unit in 2008 and 2009.

Placebo tests confirm the absence of any significant effect of the SRE scheme on industrial credit as a whole (Figure 4). Here the treated unit is moved to the control pool and the treatment effects are estimated for each of the controls using the same SCM specification. The true treatment gap (indicated by the dark black line) can be compared with the treatment gaps estimated under the placebo tests (indicated by the grey lines). ${ }^{23}$ As may be seen in the figure, the baseline treatment effect does not appear to be consistently larger than those from

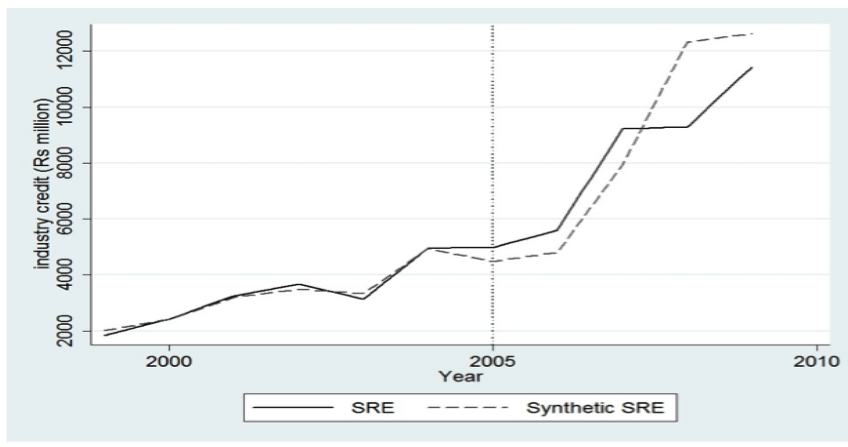

Figure 3: Industry credit trends in treated and synthetic control areas.

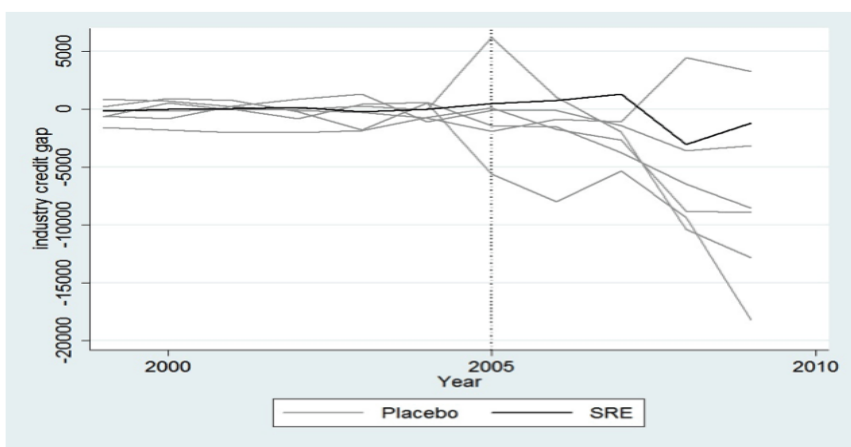

Figure 4: Placebo tests for industry as a whole.

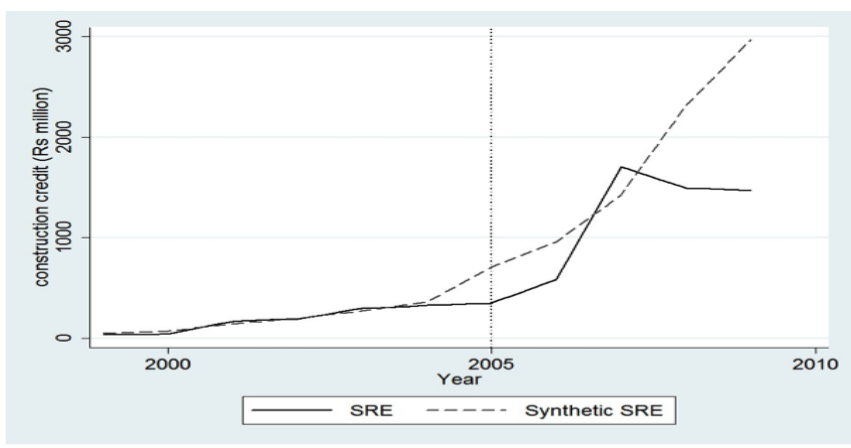

Figure 5: Construction credit trends in treated and synthetic control areas.

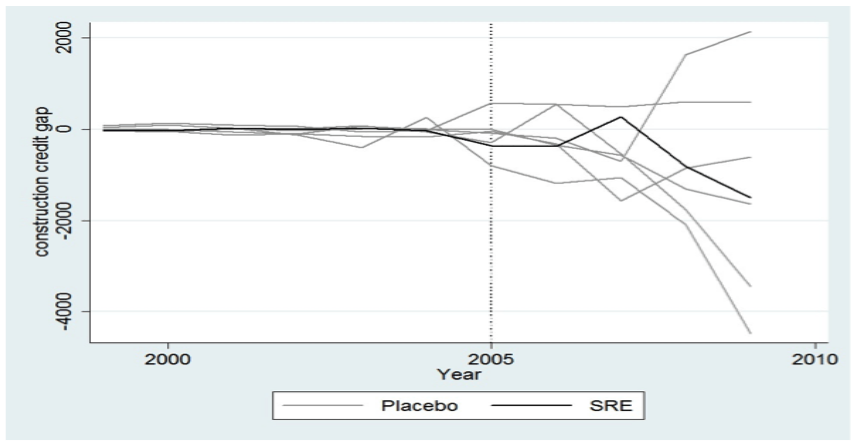

Figure 6: Placebo tests for the construction sector. 
While there is little to no effect on industrial credit taken as a whole, treatment effects may exist in particular sectors within industry. Figures 5 (treated $\mathrm{v}$ untreated districts) and 6 (placebos) show the results for the construction sector. Similarly, Figures 7 (treated v untreated) and 8 (placebos) show the results for the mining and quarrying sector.

In Figure 5 the synthetic control districts mainly comprise Cuddapah and Nellore (see Table 1), and the figure indicates no effect of the SRE scheme on the treated group of districts: In fact, the control diverges and exceeds the treated unit from 2005 onward. The placebo tests shown in Figure 6 confirm the absence of any effects.

As for mining and quarrying (Figure 7), the synthetic control consists of Cuddapah, Chittoor, Rangareddy, and West Godavari (Table 1) and credit taken in these districts is almost identical to the SRE districts until 2005 (the root mean square error in the pre-treatment period is 3.41). Thereafter, however, a wide gap between the treated unit and the synthetic control opens up and it peaks at Rs. 434 million in 2007. However, this effect vanishes by 2009. Placebo tests (Figure 8) provide some support for this finding as only one placebo permutation lies above the treated unit.

\section{Discussion and conclusion}

The article explores links among conflict, security, and economic outcomes in the context of the Naxalite insurgency

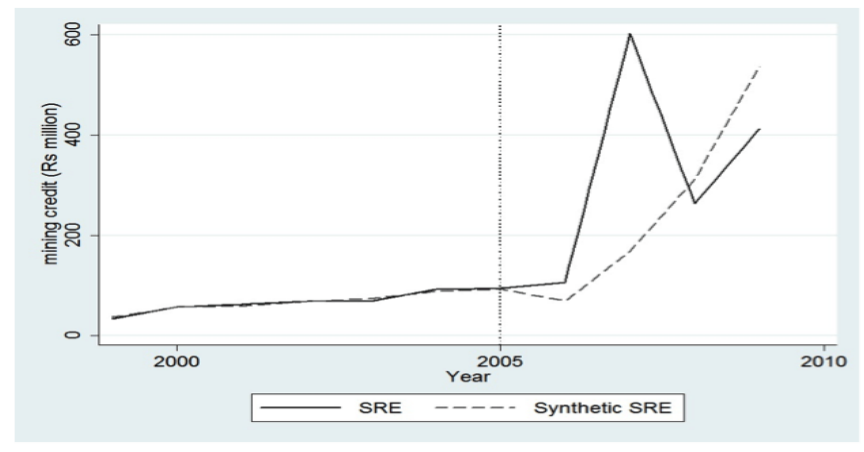

Figure 7: Mining \& quarrying credit trends in treated and synthetic control areas.
Table 1: Synthetic weights (proportions)

$\begin{array}{llll}\text { District } & \text { Total } & \text { Construction } & \text { Mining } \\ \text { Hyderabad } & 0 & 0 & 0 \\ \text { Rangareddy } & 0.21 & 0 & 0.22 \\ \text { West Godavari } & 0 & 0 & 0.05 \\ \text { Krishna } & 0 & 0 & 0 \\ \text { Nellore } & 0.37 & 0.27 & 0 \\ \text { Cuddapah (YSR) } & 0.42 & 0.72 & 0.39 \\ \text { Chittoor } & 0 & 0.01 & 0.35\end{array}$

Table 2: Predictor means

\begin{tabular}{lrrrrr} 
Covariate & \multicolumn{1}{c}{ SRE } & ------Synthetic control------- Controls \\
& & Total & Construction & Mining & average \\
Violence index & 3.88 & 2.43 & 2.01 & 2.43 & 2.57 \\
Pop. density & 272.56 & 244.75 & 245.29 & 307.89 & $2,721.00$ \\
SC/ST pop. (\%) & 24.57 & 22.98 & 21.58 & 19.76 & 20.15 \\
Literacy rate & 55.50 & 64.37 & 63.53 & 65.42 & 68.86 \\
Av. pc. cons. exp. & 669.24 & 654.46 & 691.25 & 659.00 & 806.96 \\
Gini coeff. & 0.29 & 0.29 & 0.30 & 0.30 & 0.31 \\
Unemployment rate & 1.42 & 1.36 & 1.36 & 1.09 & 1.34 \\
Urban population (\%) & 20.41 & 29.27 & 22.85 & 29.09 & 38.96 \\
Total credit (1999) & $1,841.58$ & $2,018.64$ & & & $10,037.77$ \\
Total credit (2002) & $3,674.58$ & $3,486.63$ & & & $17,518.92$ \\
Total credit (2004) & $4,958.60$ & $4,939.36$ & & & $24,558.98$ \\
Const. credit (1999) & 34.99 & & 48.45 & & 298.40 \\
Const. credit (2002) & 191.81 & & 198.39 & & $1,728.36$ \\
Const. credit (2004) & 326.77 & & 359.64 & & $4,459.21$ \\
Mining credit (1999) & 32.91 & & & 36.62 & 122.23 \\
Mining credit (2002) & 68.54 & & & 67.92 & 813.77 \\
Mining credit (2004) & 92.32 & & & 88.25 & 315.45
\end{tabular}

Note: ${ }^{*}$ Credit in millions of rupees (Rs.).

in Andhra Pradesh, India. Using industrial credit disbursed by commercial banks as a proxy for investment, it finds that the centrally funded Security Related Expenditure scheme did not affect industrial investment activity in Andhra Pradesh over the period 2005-2009. Disaggregating industrial credit taken reveals a positive effect on mining and quarrying but not on construction activity.

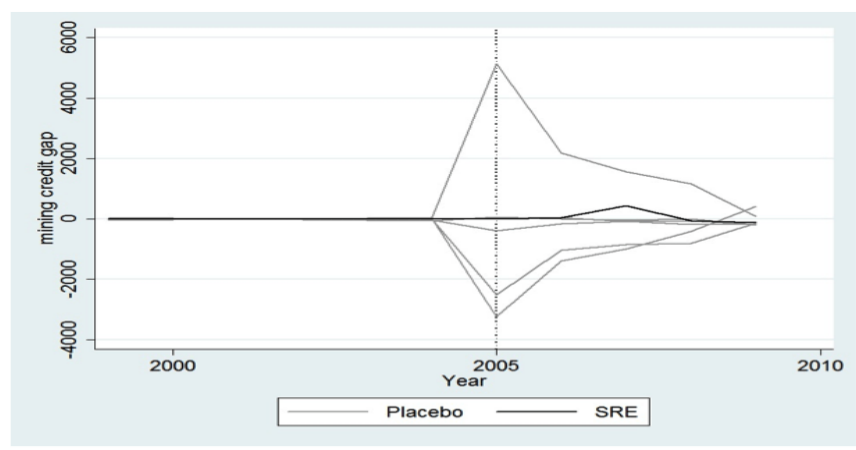

Figure 8: Placebo tests for the mining \& quarrying sector.

The Economics of Peace and Security Journal — ISSN 1749-852X — http://www.epsjournal.org.uk (C) EPS Publishing, 2014. All rights reserved. For permissions, email: ManagingEditor@epsjournal.org.uk 
It must be pointed out that the assumption of no interference between units may be violated in this case study as there may be spillovers beween the districts that were assigned to the treatment and control groups, respectively, and the net effect of which is ambiguous. It is quite possible that the flow of SRE funding to the treated districts resulted in the movement of Naxalites to the untreated districts, thereby lowering their economic activity. ${ }^{24}$ But it is also possible that since the central government was funding anti-Naxalite efforts in the treated districts, states were able to channel/divert more funds to the control districts, potentially increasing their economic activity. Another potential source of concern is the variation in treatment over time and across the districts that received the scheme. Presently the central government only provides information on the total amount of funds provided to the affected states under the SRE scheme. If more information becomes available on how the states allocated these funds to the treated districts and how they were spent, it would be interesting to analyze if variations along these dimensions affected violence and economic activity differently.

Nonetheless, the finding that in Andhra Pradesh, the SRE scheme positively affected mining and quarrying but not other industrial activity such as construction is interesting. As discussed, mining and quarrying are strategically important, and it is possible that SRE funds are not improving the security environment in general but only for certain activities such as mining. Future work may extend this kind of analysis to other states covered under the scheme to learn what relationships may be uncovered there. This is important given that the affected states are asking for a further expansion of the scheme. $^{25}$

\section{Notes}

1. Use of economic indicators: Kapstein, (2012). Lebanon: Sobel (1998); Sri Lanka (Coyne, et al., 2010); Iraq (Chaney, 2008; Amara, 2012).

\section{Paper from 2012: Singhal and Nilakantan (2012).}

3. "It would not be an exaggeration to say that the problem of Naxalism is the single biggest internal security challenge ever faced by our country ..." PM's speech at the Chief Minister's meeting on Naxalism. http://pmindia.gov.in/speech-details. php?nodeid=302 [accessed 16 January 2014].

4. Weapons used: Ramana (2006). Attack on minister: The Hindu (2003).

5. Targets: Ramana (2009b). Blockade: Srivastava (2007). Kidnapping and protection money: Pandey (2009) reports that the lure of extortion revenue was leading to turf wars between Naxal groups. Rs. 10 billion: Singh and Diwan (2010). More recent investigations peg this closer to Rs. 20 billion (The Times of India, 2011). Investigations also reveal poppy cultivation to be another important source of revenue. Dampened investment: (The Economic Times, 2010).

6. Little effect: See, g., Jha (2009). This is stressed in point 3 of the government's 14-point policy against the Naxalites: "Naxalism being an inter-state problem, the states will adopt a collective approach and pursue a coordinated response to counter it." (Ramana, 2009a).

7. The exact criteria used for selection under SRE and the full list of expenditure covered are available on the website of the Ministry of Home Affairs: http://www.mha.nic.in/sites/ upload_files/mha/files/NM-SRE-Scheme_0.pdf [accessed 16 October 2013].

8. Some of this increase in the number of districts comes from large districts being split into smaller ones.

9. The funds released under the SRE scheme in 2010-11 totaled to Rs. 2.99 billion indicating the dramatic shift in policy. See Hindustan Times (2011).

10. Repeated requests: See, e.g., Pattnaik (2009). Expanded list: Hindustan Times (2011).

11. Recruited: Achutham (2010); Raju (2010). Widely credited: See, e.g., Sahni (2007).

12. Assassinated: Times of India (1993). Greyhound numbers: Shatrugna (1989); Priyadershi (2009). Similar forces in other states: Tiwari (2009).

13. A 2012 paper: Singhal and Nilakantan (2012).

14. Improved counterinsurgency by regular police force: Sahni (2008).

15. SCM: See Abadie and Gardeazabal (2003); Abadie, et al. (2010).

16. This is a brief summary. See Abadie and Gardeazabal (2003) and Abadie, et al. (2010) for details.

17. It can be shown: See Abadie, et al. (2010).

18. Literature: Abadie, et al. (2010).

19. Continental India: Though Andhra Pradesh was the leading state, offshore areas accounted for 27 percent of the value of mineral output in India. Baryites and mica: Government of India (2011). Northern Ireland: Besley and Mueller (2012).

20. Naxalite activity: From Ramana (2008). Details on data sources are available directly from the author.

21. Treated districts are Anantapur, Adilabad, East Godavari, Guntur, Karimnagar, Khammam, Kurnool, Medak, Mehboobnagar, Nalgonda, Prakasam, Srikakulam, Visakhapatnam, Vizianagaram, Warangal and Nizamabad. Non-treated districts: Rangareddy, West Godavari, Krishna, Nellore, Chittoor, Cuddapah and Hyderabad. The untreated group is restricted to the state of Andhra Pradesh to ensure that they are similar to the treated districts in all other respects.

22. For more information, see the press release by the Ministry of Home Affairs at http://pib.nic.in/newsite/erelease.aspx? relid=79472 [accessed 16 January 2014]. 
23. The placebo tests of Hyderabad are excluded in the analysis. As Hyderabad does not lie in the convex hull of its control pool, no combination of weights can find a good fit for it in the pretreatment period.

24. For instance, Hoelscher, et al. (2012) find empirical evidence of spillover across neighboring districts.

25. The Hindu (2013).

\section{References}

Abadie, A. and J. Gardeazabal. 2003. "The Economic Costs of Conflict: A Case Study of the Basque Country." American Economic Review. Vol. 93, No. 1, pp. 113-132. http://dx.doi.org/10.1257/000282803321455188

Abadie, A., A. Diamond, and J. Hainmueller. 2010. "Synthetic Control Methods for Comparative Case Studies: Estimating the Effect of California's Tobacco Control Program." Journal of the American Statistical Association. Vol. 105, No. 490, pp. 493-505. http://dx.doi.org/10.1198/jasa.2009.ap08746

Achuthan, J.K. 2010. "Tackling Maoists: The Andhra Paradigm." Indian Defence Review. Vol. 25, No. 2. http://www.indiandefencereview.com/news/tacklingmaoists-the-andhra-paradigm/ [accessed 16 January 2014].

Amara, J. 2012. "Implications of Military Stabilization Efforts on Economic Development and Security: The Case of Iraq." Journal of Development Economics. Vol. 99, No. 2, pp. 244-254.

http://dx.doi.org/10.1016/j.jdeveco.2012.02.001

Besley, T. and H. Mueller. 2012. "Estimating the Peace Dividend: The Impact of Violence on House Prices in Northern Ireland." American Economic Review. Vol. 102, No. 2, pp. 810-833. http://dx.doi.org/10.1257/aer.102.2.810

Chaney, E. 2008. "Assessing Pacification Policy in Iraq: Evidence from Iraqi Financial Markets." Journal of Comparative Economics. Vol. 36, No. 1, pp. 1-16. http://dx.doi.org/10.1016/j.jce.2007.11.003

Coyne, C.J., G.M. Dempster, and J.P. Isaacs. 2010. "Asset Values and the Sustainability of Peace Prospects." Quarterly Review of Economics and Finance. Vol. 50, No. 2, pp. 146-156.

http://dx.doi.org/10.1016/j.qref.2009.12.002

Government of India. 2011. "Ministry of Mines Annual Report 2010-11." New Delhi: Government of India. http://mines.nic.in/index.aspx?lid=549\&level=2\&chk $=24 \mathrm{dfe} 45 \mathrm{y} 5 \mathrm{edf} 5 \mathrm{e} 3$ [accessed 16 January 2014].

[Hindustan Times] 2011. "Government to pump in Rs. 6 billion to fight Maoists." Hindustan Times. 13 January 2011. http://www.hindustantimes.com/India-news/ NewDelhi/Government-to-pump-in-Rs-6-billion-to-fightMaoists/Article1-649858.aspx [accessed 5 January 2014].

Hoelscher, K., J. Miklian, and K.C. Vadlamannati.2012. "Hearts and Mines: A District-level Analysis of the Maoist Conflict in India." International Area Studies Review. Vol. 15, No. 2, pp. 141-160. http://dx.doi.org/10.1177/2233865912447022

Jha, O.P. 2009. “Combating Left Wing Extremism: Is Police Training Lacking? Case Study of Chhattisgarh." IDSA Occasional Paper.No. 3. http://www.idsa.in/system/files/ OP3_LeftWingExtremism_osjha.pdf[accessed 16 January 2014].

Kapstein, E.B. 2012. "Measuring Progress in Modern Warfare." Survival: Global Politics and Strategy. Vol. 54, No. 1, pp. 137-158.

Pandey, P. 2009. "Naxal ranks split over share in extortion spoils, say cops." The Indian Express. 13 December 2009. http://www.indianexpress.com/news/naxal-ranks-split-ov er-share-in-extortion-spoils-say-cops/553489/ [accessed 5 January 2014].

Pattnaik, S. 2009. "Old grouse on states' Naxal agenda." Hindustan Times. 16 August 2009. http:/www.hindustantimes.com/India-news/Bhubaneshw ar/Old-grouse-on-states-Naxal-agenda/Article1-443823.a spx [accessed 16 October 2013].

Priyadershi, V. 2009. "Fighting Left-Wing-Extremism through Special Task Forces." Centre for Land Warfare Studies Articles. No. 1362. http://www.claws.in/index.php?action= master\&task $=363 \& u$ id $=96$ [accessed 10 January 2014].

Raju, R.V. 2010. "Countering the Naxal Threat-II: A Case for Specialized Units." Institute of Peace and Conflict Studies Articles. No. 3150. http://www.ipcs.org/article/india/ countering-the-naxal-threat-ii-a-case-for-specialized-unit s-3150.html [accessed 16 October 2013].

Ramana, P.V. 2006. "The Maoist Movement in India." Defense \& Security Analysis. Vol. 22, No. 4, pp. 435-449. http://dx.doi.org/10.1080/14751790601104464

Ramana, P.V. ed. 2008. The Naxal Challenge: Causes, Linkages, and Policy Options. Delhi: Pearson Education India.

Ramana, P. V. 2009a. "A Critical Evaluation of the Union Government's Response to the Maoist Challenge." Strategic Analysis. Vol. 33, No. 5, pp. 745-759. http://dx.doi.org/10.1080/09700160903081285

Ramana, P.V. 2009b. "Maoists' Attacks on Infrastructure." IDSA Comment. http://www.idsa.in/idsastrategic comments/MaoistsAttacksonInfrastructure_PVRamana 200209 [accessed 16 October 2013].

Reserve Bank of India. "Basic Statistical Returns of the Scheduled Commercial Banks of India." (Various issues). http://www.rbi.org.in/scripts/publications.aspx? publication=Annual [accessed 16 October 2013].

Sahni, A. 2007. "Andhra Pradesh: The State Advances, the Maoists Retreat." South Asia Intelligence Review Weekly Assessments \& Briefings. Vol. 6, No. 10. www.satp.org/ satporgtp/sair/Archives/6_10.htm [accessed 16 January 2014].

Sahni, A. 2008. "Fighting the Maoists with Mantras." South Asia Intelligence Review Weekly Assessments \& Briefings. Vol. 7, No. 2. www.satp.org/satporgtp/sair/Archives/ 7_2.htm [accessed 16 January 2014].

Shatrugna, M. 1989. "NTR and the Naxalites." Economic and 
Political Weekly. Vol. 24, No. 28, p. 1570.

Singh, A.K. and S.B. Diwan. 2010. "Red Money." South Asia Intelligence Review Weekly Assessments \& Briefings. Vol. 8, No. 39. www.satp.org/satporgtp/sair/Archives/ sair8/8_39.htm [accessed 16 October 2013].

Singhal, S. and R. Nilakantan. 2012. "Naxalite Insurgency and the Economic Benefits of a Unique Robust Security Response." Households in Conflict Network (HiCN). Working Paper 127.

Sobel, R.S. 1998. "Exchange Rate Evidence on the Effectiveness of United Nations Policy." Public Choice. Vol. 95, No. 1-2, pp. 1-25. http://dx.doi.org/10.1023/A:1004971230542

Srivastava, D. 2007. "Economic Blockade: Will the Maoists' New Strategy Succeed?" Institute of Peace and Conflict Studies Articles. No. 2332. http://www.ipcs.org/article/ naxalite-violence/economic-blockade-will-the-maoists-ne w-strategy-succeed-2332.html [accessed 16 October 2013].

[The Economic Times] 2010. "Maoists threaten to hit India Inc's investment plans." The Economic Times.8 April 2010. http://articles.economictimes.indiatimes.com/ 2010-04-08/news/27624387_1_rowghat-iron-ore-dalli-raj hara [accessed 16 October $201 \overline{3}$ ].

[The Hindu] 2003. "Chandrababu Naidu survives landmine blast." The Hindu. 2 October 2003. http://www.hindu.com/2003/10/02/stories/200310020756 0100.htm [accessed 16 October 2013].

[The Hindu] 2013. "Madhya Pradesh wants more money to fight Naxals." The Hindu. 5 June 2013. http://www.thehindu.com/news/national/other-states/mad hya-pradesh-wants-more-money-to-fight-naxals/article47 82335.ece [accessed 16 October 2013].

[The Times of India] 1993. "Vyas murder shocks AP capital." The Times of India. 29 January 1993.

[The Times of India] 2011. "Extortnomics: Maoists raise Rs 2,000 crore every year." The Times of India. 15 February 2011. http://articles.timesofindia.indiatimes.com/ 2011-02-15/india/28541752_1_vishwa-ranjan-maoists-ex tortion [accessed 5 January 2014 ].

Tiwari, A. 2009. "Naxal-hit states to form Greyhound-like force." The Times of India. 7 February 2009. http://articles.timesofindia.indiatimes.com/2009-02-07/in dia/28058680_1_naxal-hit-states-maoist-hit-greyhounds [accessed 5 January 2014]. 